\title{
Anemia and adherence to oral iron supplementation in a sample of children assisted by the public health network of Rosario, Santa Fe
}

\author{
Logan Christensen, M.D. ${ }^{a}$, Yanina Sguassero, M.D., ${ }^{b}$ and Cristina B Cuesta, B.S. ${ }^{b}$
}

\begin{abstract}
Introduction. Medicinal iron supplementation is a free and widely used intervention to prevent and treat childhood anemia.

Objectives. To determine the prevalence of anemia in a sample of children from Rosario, to describe the use of iron supplements in children included in the studied sample, and to illustrate variables potentially related to mothers' adherence to oral iron administration.

Population and methods. A cross-sectional study involving mothers and infants younger than 42 months old assisted by the public health network of Rosario from December 2011 to April 2012 was conducted.Sociodemographic variables and data on children's health, growth, anemia, and iron administration were collected. A rapid test was used to determine hemoglobin level.

Results. A total of 325 mother-infant dyads were included. The overall prevalence of anemia was $40 \%$ (95\% CI: $35-45 \%$ ), and it increased up to $56 \%$ in the 6-23 month old group. Fifty-one percent of mothers reported that their children had at some time received iron. Mothers' adherence to oral iron administration was higher in the group of children without anemia in comparison to those with anemia (OR: 0.28; 95\% CI: 0.1-0.69). The most common causes for lack of adherence included gastrointestinal intolerance (38\%) and forgetfulness (36\%).

Conclusions. Prevalence of childhood anemia in the studied sample was high. A lower mothers' adherence to iron administration was observed in the group of children with anemia.

Keywords:anemia, infants, iron, oraladministration, adherence to medication.
\end{abstract}

http:/ /dx.doi.org/10.5546/aap.2013.288

b. Centro Rosarino de Estudios Perinatales. Rosario, Argentina.

Funding: Duke Global Health Institute, Field Study Grant. Duke University, Durham NC, USA.

E-mail:

Yanina Sguassero, M.D.: ysguassero@crep.org.ar

Conflict of interest: None.

Received: 10-15-2012 Accepted: 02-26-2013

\section{INTRODUCTION}

According to WHO data for 35 countries in the region of the Americas, the prevalence of anemia in preschool children is $47 \%$ (approximately 23 million children). ${ }^{1}$ It is assumed that half of the cases of anemia are caused by iron deficiency, the most prevalent nutritional deficiency in low- and middle-income countries. $^{2}$

The measurements of hemoglobin $(\mathrm{Hb})$ and serum ferritin levels are the two most common lab tests used for the diagnosis of irondeficiency anemia. Although it is currently unknown from which level iron deficiency is considered to cause harmful effects, ${ }^{3}$ the WHO recommends the following thresholds for children aged 6-23 months old: $\mathrm{Hb}<11 \mathrm{~g} / \mathrm{dL}$ and ferritin $<10-$ $12 \mu \mathrm{g} / \mathrm{L} .{ }^{4}$ There is no consensus regarding the definition of anemia in infants younger than 6 months old; $9.5 \mathrm{~g} / \mathrm{dL}$ is one of the cut off points recommended for $\mathrm{Hb} .^{5}$

Most studies on anemia prevalence in South America were conducted in Brazil and have reported a prevalence of up to $30-64 \%{ }^{6-10}$ (details on the search strategy are available upon request to the main author). In Argentina, the most representative data were obtained from the National Survey on Nutrition and Health in Argentina 2005. ${ }^{11}$ Results revealed a total prevalence of anemia (defined as $\mathrm{Hb}<11 \mathrm{~g} / \mathrm{dL}$ ) of $16 \%$ in infants aged 6 to 60 months old, which increased to $34 \%$ in infants aged 6 to 23 months old.

Interventions aimed at preventing childhood anemia have been classified based on their impact over time: ${ }^{12}$
- Short-term: late umbilical cord clamping, ${ }^{13}$ promotion of exclusive breastfeeding, timely introduction of supplementary feeding, and medicinal iron supplementation.

- Medium-term: iron fortified foods.

- Long-term: food and nutrition education programs, parasite treatment campaigns, environmental sanitation, and community education strategies. 
In 2009, the Sociedad Argentina de Pediatria published a national Guideline for the prevention and treatment of iron-deficiency anemia. ${ }^{4}$ Based on these recommendations, lab tests for anemia should be prescribed to all infants aged 9 to 12 months old. In addition, prophylactic dosage of ferrous sulfate should be prescribed for higher risk children, i.e. preterm newborn infants, twins, and term infants fed with cow milk or breast milk but with a low-iron diet as of 6 months old. In all cases, iron administration should extend up to 1218 months old.

Ferrous sulfate is a drug provided at no cost through a National Program (Programa Nacional Remediar). ${ }^{15}$ Several studies have been published in Argentina regarding the factors that might interfere with iron supplementation in the populations that receive it. ${ }^{16-18}$

A review published by Lutter, et al. ${ }^{19}$ demonstrated the effectiveness of supervising iron supplementation adherence for the reduction of childhood anemia prevalence, while other studies ${ }^{20,21}$ about alternative strategies reported controversial results.

The main objectives of this study were to determine the prevalence of anemia in a sample of children from Rosario, to describe the use of iron supplementation in children included in the studied sample, and to illustrate variables potentially related to mother's adherence to oral iron administration.

\section{POPULATION AND METHODS}

In the context of an international project on early child development, ${ }^{22}$ a cross-sectional, descriptive study was conducted in the public health network of Rosario. Health care centers were selected based on the availability of a pediatrician interested in collaborating with the project and adequate facilities for interviewing mothers. Five sites took part in the study: Hospital de Niños V. J. Vilela, Maternidad Martin, Centro de Atención Primaria Eva Duarte, Hospital J. B. Alberdi, and Hospital Escuela Eva Perón. The study sample was selected based on the reference population of participating sites, and included mothers and infants younger than 42 months old assisted at the outpatient Pediatrics Department between December 2011 and April 2012.

Local exclusion criteria applied at the time of asking mothers to take part in the study included: diagnosis of genetic or neurological conditions, infections, and fever.

Data were collected by investigators trained to this end. Outcome measures for this study were: age (in years), mother's marital status, mother's education level (in years), housing conditions (running water, type of toilet flushing system, brick or cement walls, power, refrigerator, TV), child benefit (yes/no), birth weight (in grams), duration of breastfeeding (in months), history of malnutrition, anemia, and iron administered to the child (yes/no).

If the mother indicated that her infant had ever received iron, the following additional information was requested: name of iron supplement, age (in months) at the onset of supplementation, current iron administration (yes/no), age (in months) at the end of supplementation.

Mothers' adherence was evaluated in the group of infants receiving iron for at least one month or in those who had discontinued it less than six months prior to the interview. In this group of mothers, additional information was collected by making the following open question: How did you give iron to your child last week? Then the mother was asked whether this had been prescribed by the pediatrician.

If the mother indicated that her infant had never taken iron or if mothers showed poor adherence, they were openly asked about the reason for this.

$\mathrm{Hb}$ levels were measured with a portable hemoglobinometer ${ }^{23}$ using one drop of blood drawn from the child's index finger. Test results were submitted to the pediatrician, and the child's weight $(\mathrm{kg})$, length/height $(\mathrm{cm})$, and head circumference $(\mathrm{cm})$ were recorded during the visit.

The following definitions were used:

- Exclusive breastfeeding: infant fed exclusively with breast milk (included expressed milk and from a wet nurse), who may also receive drops, syrups (vitamins, minerals, medications) during his/her first six months of life.

- Low weight: weight for age below -2 standard deviations (SD) from the median weight for age of reference population in Argentina.

- Low height: length/height below -2 SD from the median length/height for age of reference population in Argentina.

- Wasting: weight for length/height below -2 $\mathrm{SD}$ from the median length/height for age of reference in Argentina.

- Anemia: serum hemoglobin below $11 \mathrm{~g} / \mathrm{dL}$ in infants aged $\geq 6$ months old ${ }^{4,11,12}$ and below 9.5 $\mathrm{g} / \mathrm{dL}$ in infants aged $<6$ months old. ${ }^{5}$

- Adherence: oral iron administration $\geq 5$ days / 
week and according to medical prescription.

- Poor adherence: oral iron administration $<5$ days/week or treatment discontinuation in spite of medical prescription.

Data analysis was performed for the sample as a whole and for the following age groups: $<6$ months, 6-23 months, and $\geq 24$ months. The SAS 9.2 software was used for statistical analyses. ${ }^{24}$ Categorical outcome measures were expressed as percentages. The $95 \%$ confidence interval (CI) was also calculated for primary outcomes. Continuous outcome measures were expressed as mean and standard deviation. Study group comparisons were done using Fisher's exact test. Associations between maternal adherence to iron administration and outcome measures, and between iron administration and anemia were estimated using univariate and multivariate logistic regression analyses. The statistical significance level was established at $\alpha=0.05$.

The approval of the Ethics Committee and the Primary Health Care Department of Rosario City was obtained, together with the support of the Independent Ethics Committee of Centro Rosarino de Estudios Perinatales. The informed consent was obtained from the parents before including their infant in the study.

\section{RESULTS}

A total of 325 mother-infant dyads were included. Children were grouped by age: younger than 6 months old $(89 / 325 ; 27.4 \%)$, from 6 to 23 months old $(156 / 325 ; 48 \%)$, and from 24 to 42 months old $(80 / 325 ; 24.6 \%)$. The overall characteristics of the study sample are presented in Table 1. In the maternal population, the mean age was $26.8 \pm 6.6$ years old, $44.3 \%$ said that they had not completed secondary education, and $50.6 \%$ were being paid a child benefit (Universal Child Allowance program in Argentina). The pediatric study population in general did not have growth disorders, and more than half of the children had received exclusive breastfeeding.

The overall prevalence of anemia was $40 \%$ (95\% CI: 35-45\%). The subgroup analysis showed differences between the preset age groups: $19.1 \%$ (95\% CI: $10-26 \%$ ) in infants younger than 6 months old, $55.8 \%$ (95\% CI: 48-64\%) in children aged 6-23 months old, and 32.5\% (95\% CI: $22-43 \%)$ in children older than 24 months old $(p<0.0001)$. Figure 1 shows the distribution of hemoglobin levels for each age group.
In relation to the use of oral iron supplements, $51.1 \%(166 / 325)$ of the mothers indicated that their children had taken them at least once. Breaking down such data by age group, it was observed that iron supplement administration in infants younger than 6 months old was infrequent $(6 / 89 ; 6.7 \%)$ when compared to children aged $6-23$ months old $(106 / 156 ; 68 \%)$ and those aged $\geq 24$ months old $(54 / 80 ; 67.5 \%)$.

When considering the 6-23 months old group, one third $(48 / 156)$ of the mothers stated they were administering iron to their child at the time of being included in the study: 23 had anemia (23/87; $26.4 \%)$ and 25 did not have anemia (25/69; 36.2\%). The logistic regression analysis related to the "child age" outcome measure showed a significant difference $(p=0.025)$.

Furthermore, mothers of children who had never received iron in this age group (50/156; $32 \%$ ) said that the supplement had not been prescribed by their doctors.

With the aim to investigate adherence to oral iron administration, mothers who stated that they had given iron to their children at least once, regardless of their age, and who met the study requirements were considered for inclusion. The level of adherence of mothers studied $(n=83)$ was 54\% (CI: 43-65\%). When analyzing this outcome measure according to the $\mathrm{Hb}$ rapid test strip results, findings indicated that in the group of children with anemia maternal adherence was 39\%, versus $70 \%$ of adherence in the group of children without anemia (OR: 0.28; 95\% CI: 0.11-0.69). Reasons for the lack of adherence were: gastrointestinal intolerance $(38 \%)$, forgetfulness $(36 \%)$, personal decision by the mother $(11 \%)$, lack of understanding $(6 \%)$, problems accessing the health system $(3 \%)$, and others, including allergies or fever $(6 \%)$.

The potential association between mothers' adherence to iron administration to their children and the following outcome measures was examined: mother's age and education level (in years), history of childhood anemia as described by the mother (yes/no), exclusive breastfeeding (yes/no), toilet flushing system (yes/no), and child benefit (yes/no). The two last outcome measures made it possible to define a group of families with a lower social level in spite of the sample homogeneity and that no specific socio-economic data were collected.

A higher level of adherence to iron supplement administration was observed in older mothers (OR: 1.04; 95\% CI: 0.97-1.11) and in those with a higher level of education (OR: 1.14; 95\% CI: 0.94- 
TABLE 1. Characteristics of mothers and children included in the study

\begin{tabular}{|c|c|c|c|c|}
\hline & $\begin{array}{l}\text { Total sample } \\
\quad(n=325)\end{array}$ & $\begin{array}{c}<6 \text { months old } \\
(n=89)\end{array}$ & $\begin{array}{c}\text { 6-23 months old } \\
(\mathrm{n}=156)\end{array}$ & $\begin{array}{c}\geq 24 \text { months old } \\
(n=80)\end{array}$ \\
\hline \multicolumn{5}{|l|}{ Characteristics of the maternal population } \\
\hline Age & $26.8 \pm 6.6$ & $26.1 \pm 6.7$ & $26.4 \pm 6.5$ & $28.4 \pm 6.5$ \\
\hline $\begin{array}{l}\text { Education level } \\
\text { Incomplete primary education } \\
\text { Complete primary education } \\
\text { Incomplete secondary education } \\
\text { Complete secondary education } \\
\text { Tertiary level }\end{array}$ & $\begin{array}{c}10(3.1 \%) \\
69(21.2 \%) \\
144(44.3 \%) \\
69(21.2 \%) \\
33(10.1 \%)\end{array}$ & $\begin{array}{c}2(2.2 \%) \\
19(21.4 \%) \\
37(41.6 \%) \\
21(23.6 \%) \\
10(11.2 \%)\end{array}$ & $\begin{array}{c}4(2.6 \%) \\
39(25 \%) \\
66(42.3 \%) \\
37(23.7 \%) \\
10(6.4 \%)\end{array}$ & $\begin{array}{c}4(5 \%) \\
11(13.8 \%) \\
41(51.3 \%) \\
11(13.8 \%) \\
13(16.3 \%)\end{array}$ \\
\hline $\begin{array}{l}\text { Characteristics of children population } \\
\text { Girls } \\
\text { Birth weight }<2500 \mathrm{~g} \\
\text { Duration of breastfeeding (in months) } \\
\text { Exclusive breastfeeding }{ }^{1}\end{array}$ & $\begin{array}{c}155(47.7 \%) \\
29(8.9 \%) \\
9 \pm 7.9 \\
179(55.3 \%)\end{array}$ & $\begin{array}{c}47(52.8 \%) \\
7(7.8 \%) \\
2.2 \pm 1.6 \\
61(68.5 \%)\end{array}$ & $\begin{array}{c}70(44.9 \%) \\
11(7 \%) \\
9.9 \pm 5.9 \\
79(50.6 \%)\end{array}$ & $\begin{array}{c}38(47.5 \%) \\
11(13.8 \%) \\
15.1 \pm 9.5 \\
39(49.4 \%)^{1}\end{array}$ \\
\hline $\begin{array}{l}\text { Growth }^{2} \\
\text { Without deficiency } \\
\text { Low weight } \\
\text { Low height } \\
\text { Wasting }\end{array}$ & $\begin{array}{c}278(90.6 \%) \\
1(0.3 \%) \\
16(5.2 \%) \\
12(3.9 \%)\end{array}$ & $\begin{array}{c}74(88.1 \%) \\
0(0 \%) \\
6(7.1 \%) \\
4(4.8 \%)\end{array}$ & $\begin{array}{c}133(89.9 \%) \\
1(0.7 \%) \\
8(5.4 \%) \\
6(4.1 \%)\end{array}$ & $\begin{array}{c}71(94.7 \%) \\
0(0 \%) \\
2(2.7 \%) \\
2(2.7 \%)\end{array}$ \\
\hline Anemia & $130(40 \%)$ & $16(19.1 \%)$ & $87(55.8 \%)$ & $26(32.5 \%)$ \\
\hline Child benefit ${ }^{1}$ & $164(50.6 \%)$ & $37(42 \%)^{1}$ & $79(50.6 \%)$ & $48(60 \%)$ \\
\hline
\end{tabular}

*Categorical outcome measure: $\mathrm{n}(\%)$; continuous outcome measure: mean \pm standard deviation.

Threshold value for hemoglobin in children $<6$ months old: $9.5 \mathrm{~g} / \mathrm{dL}$. and in children $\geq 6$ months old: $11 \mathrm{~g} / \mathrm{dL}$.

${ }^{1}$ One missing data; ${ }^{2} 18$ missing data.

FIGURE 1. Distribution of hemoglobin values $(g / d L)$ by age group

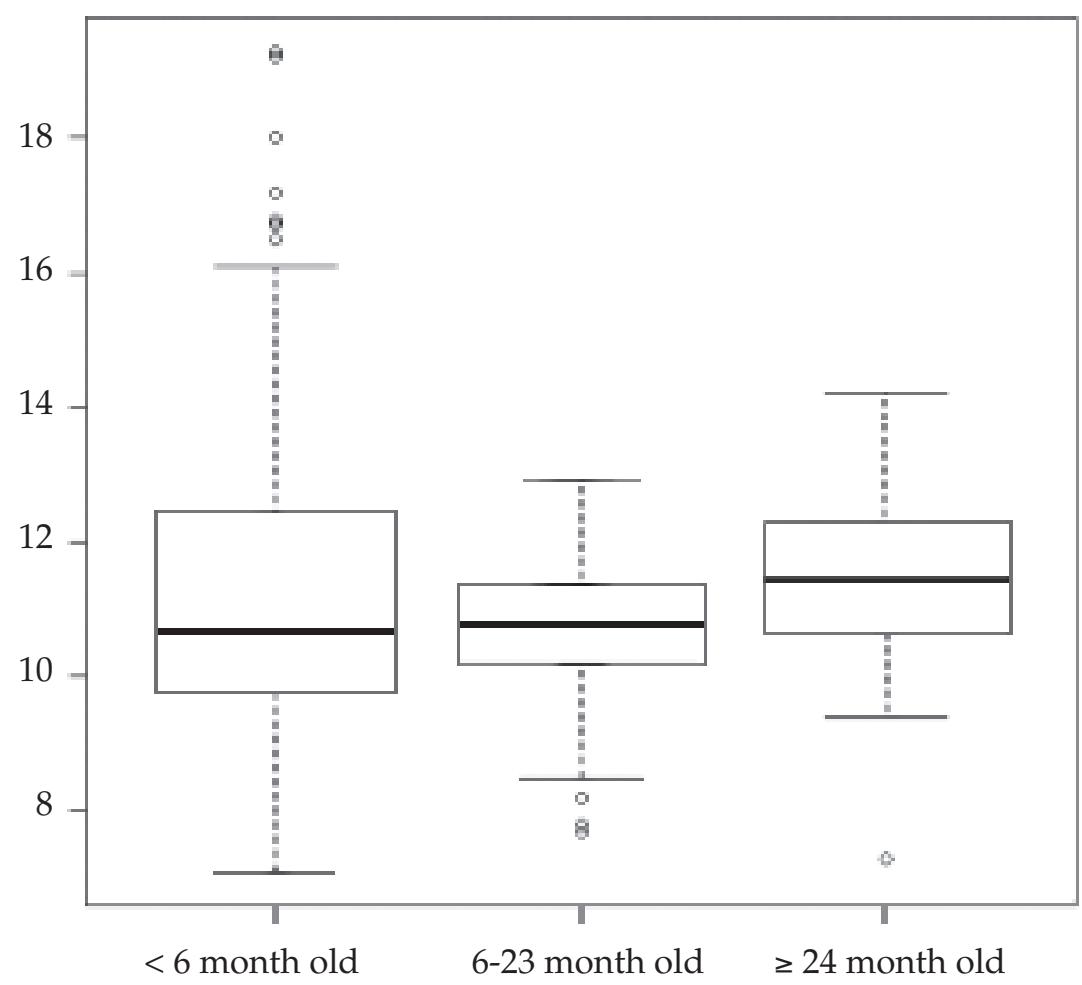


1.38), but these associations were not significant (Table 2).

\section{DISCUSSION}

The prevalence of anemia in the studied sample varied among the different age groups. The prevalence in infants younger than 6 months old was $19 \%$. This finding may be explained, among other reasons, by the maternal nutritional status and the low implementation of late umbilical cord clamping. In the 6-23 month old group, more than half of the kids had anemia. This result underscores the value of iron prophylaxis as of 6 months of age as a public health strategy.

Some studies have provided specific data on the factors that may explain the high and persistent prevalence of anemia in the Argentine pediatric population. ${ }^{16,17,25}$ Unprecedentedly, our study has focused on the adherence to iron administration taking into account the answers provided by mothers when taking their children to a pediatric consultation in the public health network. In this context, at least one every two mothers did not comply with the pediatrician's indication.

The most common reason for poor adherence was "gastrointestinal intolerance." In relation to this adverse effect, results of the study conducted by Donato, et al. ${ }^{26}$ did not find any differences when comparing ferrous sulphate to ironhydroxide polymaltose complex. Based on this, it is clear how important it is to provide an adequate and timely warning on the potential undesirable effects of iron, to explain that there are other alternative treatments in case of iron supplementation intolerance, and to focus on the relevance of complying with the schedule of iron administration in order to achieve the desired effect.
The second reason usually referred by mothers was "forgetfulness." This may be related to the fact that for them it is not relevant to administer iron drops to a child that is otherwise healthy and has no low weight issues. The meaning of anemia for mothers loses significance given their lack of awareness about the harmful effects of anemia on child growth and development, and the large heterogeneity in the clinical management of irondeficiency anemia. ${ }^{16,17}$

This study had several limitations. It is assumed that most cases of anemia are caused by iron deficiency. ${ }^{2,4,11}$ Adherence to oral iron administration was determined based on mothers' answers, and these may be biased, specially recall and social desirability biases. In relation to the studied outcome measures regarding maternal adherence, the lack of statistical significance may be explained by the lack of an actual association. ${ }^{27,28}$ However, it may also be because of homogeneity in the socio-demographic characteristics of the families included in the study, given that the study focused exclusively on users of the public health network, or also because of the sample size. A few studies suggest that the specific knowledge (signs, symptoms, adverse effects, etc.) of a disease is a factor potentially associated with the degree of treatment adherence. ${ }^{29-31}$ However, this was not examined in our study.

Although findings were local, it is clear that there is a need to develop new paths of investigation aimed at identifying factors (cultural, socio-economic, medical care quality factors, among others) that may interfere with maternal adherence and the impact of oral iron supplementation on the pediatric population.

TABLE 2. Outcome variables associated with mothers' adherence to oral iron administration to their children $(n=83)$

\begin{tabular}{lcc}
\hline \multirow{2}{*}{ Outcome measure } & \multicolumn{2}{c}{ Logistic regression analysis } \\
\cline { 2 - 3 } & Univariate & $\begin{array}{c}\text { Multivariate } \\
\text { OR (95\% CI) }\end{array}$ \\
\hline Maternal education (in years) & $1.13(0.95-1.36)$ & $1.14(0.94-1.38)$ \\
Maternal age (in years) & $1.03(0.97-1.10)$ & $1.04(0.97-1.12)$ \\
History of anemia in the child & $1.60(0.67-3.84)$ & $1.64(0.65-4.15)$ \\
Exclusive breastfeeding & $0.62(0.26-1.50)$ & $0.72(0.29-1.79)$ \\
Toilet flushing system & $0.81(0.27-2.42)$ & $0.86(0.27-2.74)$ \\
Family benefit & $1.37(0.57-3.26)$ & $1.77(0.68-4.63)$ \\
\hline
\end{tabular}




\section{CONCLUSIONS}

In comparison with data available at national level, the prevalence of anemia in the children sample of our study was high. A lower maternal adherence to iron administration was observed in the group of children with anemia. No relationship was observed between the studied outcome measures and maternal adherence.

\section{Acknowledgements}

We are grateful to the mothers who accepted to be part of the study. We would like to specially thank Virginia Lencinas, B.S. and Daniela Roldán, M.D., whose collaboration made this article possible, and to Professor Eduardo Cuestas for his comments regarding the manuscript. We are also thankful to Duke's Global Health Institute and to the Centro Rosarino de Estudios Perinatales for their support.

\section{REFERENCES}

1. Worldwide prevalence of anaemia 1993-2005: WHO Global Database on Anaemia. [Accessed on: November 14, 2012]. Available at: http://whqlibdoc.who.int/ publications/2008/9789241596657_eng.pdf

2. WHO,UNICEF,UNU. Iron deficiency anaemia: assessment, prevention, and control. Aguide for programme managers. Geneva, Switzerland: World Health Organization; 2001. [Accessed: 14.11.12]. Available at: http://www.who.int/ nutrition/publications/en/ida_assessment_prevention_ control.pdf.

3. Booth IW, Aukett MA. Iron deficiency anaemia in infancy and early childhood. Arch Dis Child 1997;76(6):549-54.

4. Haemoglobin concentrations for the diagnosis of anaemia and assessment of severity. WHO/NMH/NHD/ MNM/11.1 [Accessed on: 30.11.12]. Available at: http:/ / www.who.int/vmnis/indicators/haemoglobin.pdf.

5. Domellöf M, Dewey KG, Lönnerdal B, Cohen RJ, Hermell O. The diagnostic criteria for iron deficiency in infants should be reevaluated. J Nutr 2002;132(12):3680-6.

6. Garcia MT, Granado FS, Cardoso MA. Alimentação complementar e estado nutricional de crianças menores de dois anos atendidas no Programa Saúde da Família em Acrelândia, Acre, Amazônia Ocidental Brasileira. Cad Saúde Pública 2011;27(2):305-16.

7. Netto MP, Priore SE, Sant' Ana HM, Peluzio Mdo C, et al. Prevalence and factors associated to anemia and iron deficiency in 18-to 24-month old infants. Arch Latinoam Nutr 2006;56(3):229-36.

8. Bortolini GA, Vitolo MR. Relationship between iron deficiency and anemia in children younger than 4 years. J Pediatr (Rio J) 2010;86(6):488-92.

9. Shibukawa AF, Silva EM, Ichiki WA, Strufaldi MW, Puccini RFl. Prophylaxis for iron deficiency anemia using ferrous sulfate among infants followed up at a primary healthcare unit in the municipality of Embu-SP (2003/2004). Sao Paulo Med J. 2008;126(2):96-101.

10. Hadler MCCM, Yara J, Sigulem DM. Anemia do lactente: etiologia e prevalência/. J Pediatr (Rio J) 2002; 78(4):321-6.

11. Durán P, Mangialavoria G, Biglieria A, Kogana L, Abeyá Gilardon E. Estudio descriptivo de la situación nutricional en niños de 6-72 meses de la República Argentina.
Resultados de la Encuesta Nacional de Nutrición y Salud (ENNyS). Arch Argent Pediatr 2009;107(5):397-404.

12. Lineamientos de prevención y tratamiento de la anemia en la población materno infantil. [Accessed on: 04.11.12]. Available at: http://www.ms.gba.gov.ar/sitios/ seguropublico/files/2012/03/Lineamientos-anemia.pdf.

13. Ceriani Cernadas JM, Carroli G, Pellegrini L, Ferreira M, et al. Efecto del clampeo demorado del cordón umbilical en la ferritina sérica a los seis meses de vida. Estudio clínico controlado aleatorizado. Arch Argent Pediatr 2010;108(3):201-8.

14. Comité Nacional de Hematología. Sociedad Argentina de Pediatría. Anemia Ferropénica. Guía de diagnóstico y tratamiento. Arch Argent Pediatr 2009;107(4):353-61.

15. Bernztein R. El hierro, la anemia, y el uso racional en el Programa REMEDIAR. Atención Primaria de la Salud. Boletín PROAPS Remediar 2003;1(4):4-7.

16. Bernztein R, Drake I. Subprescripción de hierro y variabilidad en el primer nivel de atención público de la Argentina. Arch Argent Pediatr 2008;106(4):320-7.

17. Sammartino G. Representaciones culturales acerca de la anemia y la suplementación con hierro. Arch Argent Pediatr 2010;108(5):401-8.

18. Galloway R, Mc Guire J. Determinants of compliance with iron supplementation: supplies, side effects, or psychology? Soc Sci Med 1994;39(3):381-90.

19. Lutter CK. Iron deficiency in young children in low-income countries and new approaches for its prevention. J Nutr 2008;138(12):2523-8

20. Ip H, Hyder SM, Haseen F, Rahman M, Zlotkin SH. Improved adherence and anaemia cure rates with flexible administration of micronutrient Sprinkles: a new public health approach to anaemia control. Eur J Clin Nutr 2009;63(2):165-72.

21. Geltman PL, Hironaka LK, Mehta SD, Padilla P, et al. Iron supplementation of low-income infants: a randomized clinical trial of adherence with ferrous fumarate sprinkles versus ferrous sulfate drops. J Pediatr 2009;154(5):738-43.

22. Development of an international guide to monitor and support child development (Project Number: 5R01HD057834-02). Research Portfolio Online Reporting Tools (RePORT), National Institutes of Health, U. S. Department of Health and Human Services. [Accessed on: August 17, 2012]. Available at: http:/ / projectreporter.nih. gov $/$ project_info_description.cfm? aid $=8118246 \&$ icde $=12$ $506745 \&$ dd param $=\&$ ddvalue $=\& d d s u b=\& c r=1 \& c s b=$ defa ult\&cs $=$ ASC

23. Muñoz M, Romero A, Gómez JF, Manteca A, et al. Utility of point-of-care haemoglobin measurement in the HemoCue-B haemoglobin for the initial diagnosis of anaemia. Clin Lab Haematol 2005;27(2):99-104.

24. SAS. SAS, the power to know. SAS Institute Inc.

25. IanicelliJC, Varea A, Falivene M, Disalvo L, et al. Prevalencia de anemia en lactantes menores de 6 meses asistidos en un centro de atención primaria de la ciudad de La Plata. Arch Argent Pediatr 2012;110(2):120-5.

26. DonatoH, Rapetti MC,Morán L,Cavo M. Hidróxido férrico polimaltosado contra sulfato ferroso en el tratamiento de la anemia ferropénica: estudio prospectivo aleatorizado. Arch Argent Pediatr 2007;105(6):491-7.

27. Lacerte $\mathrm{P}$, Pradipasen $\mathrm{M}$, Temcharoen $\mathrm{P}$, Imamee $\mathrm{N}$, Vorapongsathorn T. Determinants of Adherence to Iron/ FolateSupplementation During Pregnancy in Two Provinces in Cambodia. Asia Pac J Public Health 2011;23(3):315-23.

28. Dairo MD, Lawoyin TO. Demographic factors determining compliance to iron supplementation in pregnancy in Oyo State, Nigeria. Niger J Med. 2006;15(3):241-4. 
294 / Arch Argent Pediatr 2013;111(4):288-294 / Original article

29. JanakanN,Seneviratne R. Factors contributing tomedication noncompliance of newly diagnosed smear-positive pulmonary tuberculosis patients in the district of Colombo, Sri Lanka. Asia Pac J Public Health 2008;20(3):214-23.

30. Bilenko N, Yehiel M, Inbar Y, Gazala E. The association between anemia in infants, and maternal knowledge and adherence to iron supplementation in southern Israel. Isr Med Assoc J 2007;9(7):521-4.

31. Hironaka LK, Paasche-Orlow MK, Young RL, Bauchner H, Geltman PL. Caregiver health literacy and adherence to a daily multi-vitamin with iron regimen in infants. Patient Educ Couns 2009;75(3):376-80. 